\title{
History of marine animal populations: a global research program of the Census of marine life
}

\section{Histoire des populations animales marines. Un programme de recherche global sur le recensement de la vie marine}

\author{
Poul Holm * \\ Syddansk Universitet, Center for Maritime and Regional History, Niels Bohrs Vej 9, 6700 Esbjerg, Denmark
}

\begin{abstract}
This paper examines the relationship between history and science with regard to the marine environment. It argues that historians and scientists should collaborate to reconstruct past ecosystems. Such collaboration to shed some light on the reasons why the life in the oceans appears as it does today. With this objective in view, a global research program has been established. The History of marine animal populations (HMAP) addresses four basic questions. (1) How has the extent and diversity of these populations changed over the last 2000 years? (2) Which factors have influenced these change? (3) What has been the anthropogenic and biological significance of these changes? (4) What has been the interplay of changing marine ecosystems and human societies? The hypotheses of HMAP fall in three broad categories, dealing with questions of nature variability, such as historical population ecology, nature impact, such as climate forcing of distribution and abundance of fishes, and anthropogenic impact, such as questions of depletion and eutrophication. HMAP research teams are currently working in the Baltic, the White Sea, off southeast Australia and off the California coast.
\end{abstract}

(C) 2002 Ifremer/CNRS/IRD/Éditions scientifiques et médicales Elsevier SAS. All rights reserved.

\section{Résumé}

Cet article examine les relations entre histoire et science dans l'environnement marin. Historiens et scientifiques doivent en effet collaborer pour reconstruire les écosystèmes passés. Une telle collaboration permettra de connaître les causes d'appariation dans l'océan de la vie telle que nous la connaissons actuellement. Le programme Histoire des populations animales marines (HMAP en anglais), lancé pour cet objectif, s'intéresse à quatre aspects : (1) quels ont été les changements de la diversité et de l'extension de ces populations durant les deux derniers millénaires ? (2) quels facteurs ont influencé ces modifications ? (3) quelle fut la signification anthropogénique et biologique de ces changements? (4) quelles furent les interactions entre ces changements des écosystèmes marins et les sociétés humaines ? Les hypothèses avancées par HMAP intéressent trois champs : la variabilité naturelle, comme l'histoire de l'écologie des populations, l'impact de la nature, comme la contrainte climatique sur la distribution et l'abondance des poissons et l'impact anthropogénique, comme les questions d'eutrophisation et de dépeuplement. Les équipes du HMAP travaillent sur la Baltique, la mer Blanche, le sud-est de l'Australie et au large des côtes californiennes.

(C) 2002 Ifremer/CNRS/IRD/Éditions scientifiques et médicales Elsevier SAS. Tous droits réservés.

Keywords: History; Marine life; Census

Mots clés: Histoire; Vie marine; Recensement

History is back. Notoriously, history was deemed dead by Fukuyama (1992) who proclaimed the end of history when liberal democracy seemed to be the undoubted victor after

\footnotetext{
* Correspondence and reprints.

E-mail address: pho@hist.sdu.dk (P. Holm).
}

the dissolution of the communist bloc just 10 years ago. On a more pragmatic plane, history also has been considered if not dead, at least irrelevant to most social needs outside the business worlds of heritage and nostalgia. With the triumph of social engineering and science in the second half of the 20th century, history was widely considered to be irrelevant 
to the practical concerns of modern society. Why bother with historical remains if we can just redesign and create a new and better world? Today, however, the need for historical insight seems as pressing as ever, also for our understanding and management of the marine domain. One example of this is the Draft Science Plan of the European Science Foundation Marine Board (ESF Marine Board, 2001) which is critical of the current practice of shortsighted time-series and proposes that the information of past historical evidence be drawn upon in future research and rebuilding marine ecosystems. What has happened?

The comeback for history is based on the recognition that our world is finite. In the last two or three decades we-citizens and politicians in rich and poor countries - have come to recognize that our planet is small and vulnerable. This recognition necessitates a historical perspective on modern existence. One of the most important themes of this revitalization of history is the relation between humankind and nature. Global climate changes and scarcities of resources are again and again put on the public agenda, and as this happens our understanding of the changes of nature has become a major problem to society. The history of nature itself-and the dependency and impact of human society on nature-is the basis for a meeting between science and history.

Should history and science relate to each other at all? Even today many scientists would claim that they should not - and many historians would agree. Through most of the 20th century science and history made all possible efforts to become dissociated from each other. To scientists, true science was about the process of abstraction-to see through seemingly chaotic information and recognize recurrent patterns that could be generalized into a model, a construction of thought that would explain how natural phenomena, say of an ecosystem, interact. In the best of cases scientists would then provide a set of options for politicians to restore the balance of nature. Pure science was ahistorical in principle: only recurrent phenomena were of interest because they could be made to fit and be tested by theory. The rest, including disasters, the large apparently unpredictable and arbitrary events defied the balance of models and therefore had to be discarded, and were best left to nature's history tellers. To the historians on the other hand, nature was irrelevant in relation to the real object of history, the human population, and historians permitted themselves to regard nature as a given, an unchanging scene for human action. To the pure historian, history would carry no lessons for the future as history would never repeat itself.

In science, the problem of time has become known as the shifting baseline syndrome. The child assumes that the world as I saw it first is the natural condition of the world-and scientists may assume that the natural or original condition is equal to the first scientific description of a phenomenon. Equilibrium or steady-state models are based on a given data set, often established by scientists within the last generation (Pauly, 1995). But what happens to equilibrium if older data are introduced? We cannot know from recent information the extent of the losses that have happened, the world of the coral reefs that we have lost. When ecologists study the micro fauna of the coral reefs to obtain a measure for the health of the reefs, it is as misleading as an attempt would be to measure the health of the Serengeti savannah ecology by numbers of termites and locusts without looking at the elephants and giraffes (Jackson, 1997). The lesson to ecologists of Jackson's historical analysis of Caribbean coral reefs was that textbook descriptions of reef ecosystems were limited by the fact that the systematic description by modern biology only began in the 1950s. Jackson puts the case squarely to the ecologists: they need to turn to the historical sources and rediscover the world. Jackson's plea is being echoed by many other ecologists now doing historical work (Jackson et al., 2001; Lotze and Milewski, 2002; Mackenzie et al., 2001).

Another influential development in reinstating the historical dimension in science has been the development of paleoecology and archaeoichthyology in the past 30 years. The preservation of fish scales in anoxic bottom sediments off the coast of California provided scientists with the opportunity to reconstruct 1600 years of pelagic abundances (Soutar, 1967; Baumgartner et al., 1992; Francis et al., 2001). Unfortunately, the necessary preservation conditions seem to be extremely rare (see Finney et al., 2002 for an Alaskan freshwater example), and similar reconstructions have so far not been possible in other regions of the world. However, analysis of fish remains from archaeological sites provides a possible avenue to understanding biodiversity distribution and abundance, and studies are now being published that promise great advances in this field in the coming few years (Muniz, 1996; Enghoff, 1999).

How about the historians? Environmental history has been a growth field in the USA especially since the formation of the American Society for Environmental History in 1976. The background was probably Frederick Jackson Turner's powerful vision of the history of the country as defined by the expansion of the American frontier to the West (Turner and Jackson, 1893). While the thesis has long since been discarded, man and nature is still a lead theme in American history writing, although the predominant interest has been forest rather than marine history (but for important exceptions see McEvoy, 1988; Taylor, 1999). In Europe the Annales school of history (Braudel, 1949/1972; Ladurie, 1967/1983) did represent an interest in the interplay of man and nature, but the breakthrough of environmental history has come only in the last few years. Only in the autumn of 2001 was the European Society for Environmental History launched with 150 founding members, and at the inaugural conference only a handful of papers dealt with marine topics. Strangely, fisheries historians have been reluctant to consider the ecological context on which fishing effort is both dependent and has a considerable impact. Since 1995, the North Atlantic Fisheries History Association has held biannual 
conferences but out of the published volumes (Holm and Starkey, 1995-1999), few papers deal with the impact of harvesting on the seas. However, in recent years a few papers have indicated rising interest by historians and sociologists on the interplay of humans and the marine environment and climate (Haberle and Lusty, 2000; Hamilton et al., 2000).

The apparent negligence of historians of marine animal populations (the history of nature itself) may be due to the fact that by training historians lack the tools and theories to identify the natural fluctuations in harvests that have occurred in commercial fisheries. Further, the link between history and ecology has been impeded by the still dominant steady-state theories of the effects of harvesting. The reference points of ecologists have too frequently been the hypothesized equilibrium state, and too seldom the historical and changing state of populations. Applying historical reference points is thus doubly important: they may inform ecologists about the factors controlling marine populations, and they may inform historians of the effects of harvesting the oceans. The outcome of a possible marriage of disciplines may be conceived as historical marine ecology or marine environmental history.

In many ways the complicated interplay between man and nature calls for a new type of historical research. Science is a challenge to historians who have had hardly any statistics, not to talk of modeling, as part of their training. While academic history through the 1990s tended even to lose its contact with the social sciences to concentrate on narrative and deconstructing skills, environmental history demands a daunting command of both statistical and scientific skills. This may not bode well for the discipline. But the attraction of environmental history is the thrill of being able to challenge the steady-state mode of thought of present mainstream science, and historians can deliver not only long time-series but also critical insights into the foundation for technical-economic institutions. Crossing disciplines may even bring forth greater clarity of problem definition, theory and methods when we need to explain our moves to outsiders. The foundation is a mutual respect for the intellectual questions and problems that drive a historian and a biologist to analysis. Environmental historians do not have to become biologists, nor do biologists need to become historians. But we do need to understand enough of each other's language to exchange information and insight.

Let me sum up my case for the need for a history of the marine environment. Man has harvested the marine and aquatic environments since the earliest historical records. Animals of all kinds have been harvested, in lakes and rivers, in estuaries, along ocean shorelines, and in the open oceans. The effects of man's harvesting on the populations of animals have been of increasing significance over the previous century. Long time-series and a fuller understanding of the complicated interplay of humankind and nature are needed and can only be obtained by the marriage of maritime history and marine ecology.
To begin to undertake this challenge, a global collaborative research program, the History of Marine Animal Populations (HMAP) has developed over the past three years (Holm et al., 2001). The program has identified ecosystems and fisheries where the requisite data are likely to be obtainable from historical and paleoecological archives and contemporary ecological studies. By December 2000, we obtained a grant of a total of 1.2 million US dollars to undertake seven studies of historical ecosystems and to operate three centers to coordinate the work at the Universities of New Hampshire, USA, Hull, UK, and the University of southern Denmark. Currently some 80 researchers are working in the program, and I shall limit myself to presenting just a few early results of our work.

HMAP addresses four basic questions:

- How has the extent and diversity of marine animal populations changed and varied over the last 2000 years?

- Which factors have forced or influenced the changing extent and diversity of marine animal populations?

- What has been the anthropogenic and biological significance of changes in marine animal populations?

- What has been the interplay of changing marine ecosystems and human societies?

The answers to these questions are not going to be simple. Marine ecosystems in themselves are complex systems, and history complicates matters by adding the time dimension and the interaction of humans and the sea. Therefore, we need to test our models rigorously to alternative data sets before we accept coincidental data series as pertinent data series.

HMAP has developed a set of hypotheses that will be tested by ongoing modeling exercises. The hypotheses fall in three broad categories, dealing with questions of nature variability, such as historical population ecology, nature impact, such as climate forcing of distribution and abundance of fishes, and anthropogenic impact, such as questions of depletion and eutrophication.

A simple example is the population of cod in the Baltic Sea. When the cod suddenly disappeared in the 1980s and the fishery almost closed, it caused governments to intervene, to reduce the size of the fleet. The immediate question raised was: will the cod reappear? Is overfishing to blame? Or is the cod stock subject to natural forcing?

We still do not know, in spite of the fact that the Baltic ecosystem is probably one of the best researched in the world, and even though northern Europe has some world class fisheries research labs. The reason is the baseline syndrome. We simply do not know to what degree the population of the Baltic cod fluctuates in magnitude over time as our data do not predate the year 1900 . We know that the population was low at the beginning of the last century when the seal population was large, and that it roughly increased while the seals disappeared. Today, both seals and cod have disappeared. Man has without doubt played a role for the population of both seals and cod, and seals and cod 
are themselves competitors for food. But other and more fundamental factors are certainly at work. A convincing hypothesis is that the inflow of salt water from the North Sea into the Baltic Sea plays a role in the hatching of the cod egg. Hatching takes place only with the right salinity balance. Historical data about the oceanography are therefore desirable. But these and other hypotheses all suffer from the lack of scientific observations for the period in question. This is where the historians' archives come into play. Admittedly, they do not contain scientific observations, but the historians are still able to deliver large amounts of proxy-data, such as data that reflect the consequences of the activity that we wish to assess. Denmark is one of the richest countries in Europe in this regard. As far back as the 1500s the king's fiefs, year after year, collected the tax accounts that showed the diverse magnitudes of activities that took place at sea and by the coast. Tax was paid in actual goods such as whiting, haddock, herring, mackerel and many other types of good fish. And with these data it can be seen to what extent the fishery could exploit given species for which there was no information on population fluctuations. The history of the cod lies hidden in the archives, and when we finally understand it, we will be able to take better care of the seas. The early results show that cod was abundant in the first half of the 1600s, and again in the latter half of the 1700s. The re-occurrence of cod in the second half of the 1900 s seems to be part of a centennial pattern, perhaps related to winter storms (MacKenzie et al., 2001).

One of the world's first apparent examples of overfishing comes from California. In the beginning of the 1900s towns such as Monterey and San Diego were scenes of seething activity-where millions of tons of sardines were cooked as fish meal. Biologists were watching the fishing effort with increasing concern, and developed a population model in the 1940s with the intention of predicting allowable catches. In 1952, the statistical model was completed-one year too late as the fishery had already collapsed the year before, throwing the Californian coastal population into unemployment. This example has since been held up as a deterrent and warning, seemingly a lesson in ecological stupidity.

In the meantime, history has taken an ironic turn. Paleoecologists have counted fish scales from the last 1600 years of build up of dead fish on the sea bed, and historical research has amplified the picture for the last couple of hundred years. The results are clear: the populations of sardines, anchovies and hake fluctuate wildly, correlating - apparently in different ways-according to air pressure and changes in wind direction. The sardines were probably exposed to a high level of fishing, but disappeared from the Californian coast in accordance with the patterns which they had followed for hundreds of years. The biological model from 1952 agreed with the data that were available at that time, but a greater historical depth showed in addition, that our scientific knowledge was never better than our baseline (Francis et al., 2001).
While my previous examples have drawn attention to natural variability and climate forcing, the Australian research carried out in HMAP has produced a fascinating glimpse of the impact of human activities on a pristine ecosystem. Australian aboriginal fishing boats did not reach the SE Australian shelf-and-slope ecosystem, and the ecosystem was therefore, prior to the onset of British-style steam-trawling around 1920, virtually untouched by humans. Thanks to an impressive amount of data detection from early scientific expeditions and data rescue involving searches in the dumps of derelict businesses, the research team has constructed a time-series which shows the dramatic changes occurring in the ecosystem even from the very first years of human activity. Clearly, the evidence, which still need full assessment, indicates that the impact of human activity was very forceful and seems to have induced a regime shift by the 1940s (Tull et al., 2001).

A final example is drawn from the results of the Russian team. The team consists of researchers from St. Petersburg, Moscow and Archangel and has mined the enormous deposits of the Russian bureaucracy and the records of Russian monasteries. The monasteries conducted large fishing operations throughout Russia, and the team has been able to reconstruct salmon abundance in north Russian rivers and walrus in the White Sea since the early 1600s. The importance of this work for understanding salmon populations in Russia is self-evident but what we have is perhaps the promise of much wider interest. Thanks to the richness of the Russian evidence it lends itself as master data series which may be used for comparative research on a circumpolar basis, and for instance cast much needed new light on the abundance of Pacific salmon and even more generally on larger questions of the impact of climate systems and human activity on fish diversity, distribution and abundance (Lajus et al., 2001).

The first projects of HMAP will be concluded by the end of 2002, and results will be published in international journals while a historical data base encompassing the data generated by the projects will be published and maintained at the HMAP website to allow future historians and ecologists full access. It is envisaged that the next phase of the HMAP program will include some $15-20$ projects globally, to be completed in the next 5-8 years.

The HMAP studies will help us not only to get a better understanding of past biodiversity and abundances but potentially will inform managers of fisheries and marine habitats. Concerns have been raised that whole ecosystems have been depleted beyond restoration, and conservationists are urging the introduction of Marine Protected Areas to protect ecosystems or indeed help rebuild ecosystems to a pristine state (Pauly, 2002). Obviously, the conservationist goals need to be informed by historical analysis of what has actually been lost in the habitat and ecosystem. This raises the important question about the use of the term "pristine state", e.g. of coral reefs, or of the southern Australia marine system. What is the "pristine state" of something that 
continuously evolves and changes over time? Does "pristine state" refer to times before human interaction (as appears to be suggested for the Australian example)? How far back does this require? As the paleoecological studies cited above implicate, the idea of ecosystems being in some "pristine" (perhaps even implying stable) state is probably simply false. We need therefore to develop a much more comprehensive and analytical vocabulary and theory to not only understand the past but inform present and future policies and management.

This observation also addresses the concern of 'pure' historians cited above, namely that history does not repeat itself and therefore cannot be used to predict the future. This observation may be true but should not distract us from the much more pertinent question: to which degree can history assist us in developing scenarios for the future that we want for marine ecosystems. Here the challenges of ecology and history merge.

\section{References}

Baumgartner, T.R., Soutar, A., Ferreira-Bartrina, V., 1992. Reconstruction of the history of Pacific Sardine and Northern Anchovy populations over the past two millennia from sediments of the Santa Barbara Basin. California Cooperative Fishery Investigations Reports, 33, pp. $24-40$.

Braudel, F., 1949/1972. The Mediterranean and the Mediterranean World in the Age of Philip II (London).

Enghoff, I.B., 1999. Fishing in the Baltic region from the fifth century BC to the 16th century AD: evidence from fish bones. Archaeofauna 8 , 41-85.

ESF Marine Board. Draft Integrated Marine Science Plan (http://www.esf.org/generic/179/Version2509.pdf).

Finney, B.P., Gregory-Eaves, I., Douglas, M.S.V., Smol, J.P., 2002. Fisheries productivity in the northeastern Pacific Ocean over the past 2200 years. Nature 416, 729-733.

Francis, R.C., Field, J., Holmgren, D., Strom, A., 2001. In: Holm (Ed.). Starkey \& Smith, pp. 123-140.

Fukuyama, F., 1992. The End of History and the Last Man. Free Press.

Haberle, L., 2000. Can climate influence cultural development? A view through time. Environ. Hist. 6, 349-369.
Hamilton, et al., 2000. Social change, ecology, and climate in 20th-century Greenland. Climatic Change 47, 193-211.

Holm, P., Starkey, D.J. (Eds.), 1995-1999. Studia Atlantica 1-4. Esbjerg.

Holm, P., Smith, T.D., Starkey, D.J. (Eds.), 2001. The Exploited Seas: New Directions for Marine Environmental History. International Maritime Economic History Association/Census of Marine Life. St. John's, Newfoundland.

Jackson, J., 1997. Reefs since Columbus. Coral Reefs 16, $23-32$.

Jackson, et al., 2001. Historical overfishing and the recent collapse of coastal ecosystems. Science 293, 629-637.

Ladurie, E., 1967/1983. Histoire du Climat depuis l'An Mil (Paris).

Lajus, J., et al., 2002. Status and potential of historical and ecological studies on Russian fisheries in the White and Barents Seas: the case of Atlantic salmon. In: Holm (Ed.). Starkey \& Smith, pp. 97-122.

Lotze, H.K., Milewski, I., 2002. Two hundred years of ecosystem and food web changes in the Quoddy Region, Outer Bay of Fundy. Report by the Conservation Council of New Brunswick. Fredericton, New Brunswick, Canada 188 p.

MacKenzie, et al., 2001. Ecological hypotheses for a historical reconstruction of upper trophic level biomass in the Baltic Sea and Skagerrak. Can. J. Fish Aquat. Sci. 59, 172-190.

McEvoy, A.F., 1988. Towards an interactive theory of nature and culture: ecology, production and cognition in the California fishing industry. In: Worster, D. (Ed.), The Ends of the Earth: Perspectives on Modern Environmental History. Cambridge University Press, Cambridge, pp. 211-229.

Muniz, A.M., 1996. The evolution of the I.C.A.Z. Fish remains working group from 1981 to 1995. Archaeofauna 5, 13-20.

Pauly, D., 1995. Anecdotes and the shifting baseline syndrome of fisheries. Trends Ecol. Evol. 10 (10), 430.

Pauly, D., 2002. Global change, fisheries and the integrity of marine ecosystems: the future has already begun. In: Pimentel, D., Westra, L., Reed, R.F. (Eds.), Ecological Integrity: Integrating Environment, Conservation and Health. Island Press, Washington, DC, pp. 227-239.

Soutar, A., 1967. The accumulation of fish debris in certain Californian coastal sediments. California Cooperative Fishery Investigations Reports 11, 136-139.

Taylor, J.E., 1999. Burning the candle at both ends: historicising fishing in Oregon's 19th century salmon fisheries. Environ. Hist. 4, 54-79.

Tull, M., Polacheck, T., Klaer, N., 2001. The potential for historical studies of fisheries in Australia and New Zealand. In: Holm (Ed.). Starkey \& Smith, pp. 181-206.

Turner, F., Jackson, 1893. The frontier in American history. The Annual Report of the American Historical Association. pp. 199-227. 